\title{
INTERNATIONAL JURISDICTION RULES IN MATTERS OF PARENTAL RESPONSIBILITY IN THE EUROPEAN UNION AND BOSNIA AND HERZE- GOVINA: THE CONCEPT OF HABITUAL RESIDENCE V. NATIONALITY
}

Jasmina Alihodžić1

Faculty of Law, University of Tuzla
Original scientific paper
Faculty of Law, University of Tuzla

Received: 14.08 .2012

Accepted: 31.08 .2012
UDC: $341.9(497.6: 4-67 \mathrm{EU})$

341.96:347.63 (4-67 EU)

\begin{abstract}
The rules of jurisdiction in matters of parental responsibility contained in the Brussels II bis Regulation are based on the concept of habitual residence, while the legislation in $B \& H$ in this area gave priority to the principle of nationality. Analyzing these concepts, the author of the paper points to the importance of interpreting the concept of habitual residence by the European Court of Justice, and gives possible directions for reform of the relevant provisions of the PIL Act in terms of their compliance with EU law.
\end{abstract}

Key words: Brussels II bis Regulation, habitual residence, PIL Act, principle of nationality, harmonization, communitarization.

\section{INTRODUCTION}

Although when it comes to rules on jurisdiction in matters of parental responsibility with an interna- tional element, the legislations of some countries are based on the principle of nationality ${ }^{2}$,

\section{${ }^{1}$ Correspodence to:}

Jasmina Alihodžić, Faculty of Law, University of Tuzla

Tuzla, Bosnia and Herzegovina

Phone: +38761 730566

E-mail: jasminaalt@hotmail.com

\footnotetext{
${ }^{2}$ All states that emerged after dissolution of Yugoslavia, which after independence brought new legislation in the field of private international law, based rules on jurisdiction in matters of parental responsibility primarily on the principle of nationality (Slovenia, Macedonia). This solution was also envisaged by the the Act on the Collision of Laws with Laws of Foreign Nations in Certain Cases (Official Gazzete of SFRY, No. 43/1982, 72/82), which is still a valid regulation in Bosnia and Herzegovina and other countries of former Yugoslavia until the entry into force of new legislation in this area. Blagojević, B. (et. al.), „Nacrt zakona o međunarodnom privatnom pravu i postupku“", Prinosi, br. 7/74, p. 77 - 105. Šaula, V., Osnovi međunarodnog privatnog prava Republike Srpske, Pravni fakultet Univerziteta u Banjoj Luci, 2008, p. 64 - 67. Stanivuković, M., Živković, M., Međunarodno privatno pravo, opšti deo, Službeni glasnik, 2010., p. 38 - 39.
} 
European and international instruments pertaining to this matter gave the primacy to the concept of habitual residence, while the lex patriae approach has a marginal significance, and is generally applied extremely when the authorities of child's habitual residence determine that it is in the best interest of the child. This approach was taken in standardizing the provisions on jurisdiction in matters of parental responsibility of the Hague Convention of $1996^{3}$, which can be considered normative model for the determination of rules of jurisdiction in matters of parental responsibility contained in Brussels II bis Regulation ${ }^{4}$.

In the first part of the paper the author explains that the basis for international jurisdiction of the courts in the EU is primarily based on the concept of habitual residence. The lack of an autonomous definition of this term is compensated by the European Court of Justice interpretation given in the decision Mercredi v.Chaffe, which the author explained in the second part of the paper. The third part deals with the rules of jurisdiction with respect to relevant matters contained in the legislation of $\mathrm{B} \& \mathrm{H}$, emphasizing that $\mathrm{B} \& \mathrm{H}$ legislation gave the primacy to the principle of nationality. Considering the effects of process of communitarisation of private international law, and therefore external competence of EU to conclude international agreements with third states, it is interesting to consider the possibility for $\mathrm{B} \& \mathrm{H}$ to enter into contractual relations with EU Member States, among other areas in terms of jurisdiction in matters of parental responsibility, which the author referred to in the fourth part of the paper. At the end the author gave concluding remarks.

\footnotetext{
${ }^{3}$ Hague Convention on Jurisdiction, Applicable Law, Recognition, Enforcement and Cooperation in Respect of Parental Responsibility and Measures for the Protection of Children, 19 October 1996. Rosenblatt, J., International Conventions Affecting Children, Kluwer Law International, 2000.

${ }^{4}$ Council Regulation (EC) No 2201/2003 of 27 November 2003 concerning Jurisdiction and the Recognition and Enforcement of Judgments in Matrimonial Matters and the Matters of Parental Responsibility, repealing Regulation (EC) No 1347/2000, Official Journal of the European Union L338/1, 23. 12. 2003. Duncan, W., Nationality and the Protection of Children across Frontiers, and the Example of Intercountry Adoption, Yearbook of Private International Law, Volume 8, 2006, p. 79.
}

\section{CONCEPT OF ,HABITUAL RESIDENCE“ IN INTERNATIONAL JURISDICTION RULES IN MATTERS OF PARENTAL RESPONSI- BILITY ACCORDING TO BRUSSELS II BIS REGULATION}

With regard to the matters of parental responsibility, the Regulation applies in respect of attribution, exercise, delegation, restriction or termination of parental responsibility (Article 1 paragraph 1(b) of Brussels II bis Regulation). As defined in the Regulation, parental responsibility means the rights and duties relating to the child or his property, which the court has granted to a natural or legal person on the basis of judgment, by operation of law or by an agreement. The institute includes the rights of custody and accession rights to the child (Article 2, paragraph 7 of the Brussels II bis Regulation). Unlike Brussels II Regulation whose field of application in respect of parental responsibility referred only to the children of both spouses, provided that such action is associated with marital disputes, the Brussels II bis Regulation, whose primary objective is the protection of the interests of the child, knows no such limits, so therefore applies in cases of parental responsibility, regardless of whether the children belong to both spouses or not, and regardless of whether such a case has any connection with a matrimonial dispute ${ }^{5}$. Jurisdiction in matters of parental responsibility is determined in accordance with the objectives relating to the protection of the interests of the child, especially bearing in mind the principle of proximity, which means that the primary criterion for determining jurisdiction in accordance with the provisions of this Regulation is habitual residence of the child, except in certain cases where there is a change of residence of the child, or pursuant to a prorogation of jurisdiction by the holders of parental responsibility $^{6}$. The assessment of this concept depends primarily on the interests of the legislator ${ }^{7}$.

\footnotetext{
${ }^{5}$ Paragraph 5of the Preamble to the Brussels II bis Regulation. ${ }^{6}$ Paragraph 12 of the Preamble to the Brussels II bis Regulation ${ }^{7}$ Countries with large emigration of population largely opted for the principle of nationality, while states with significant immigration generally give primacy to the concept of habitual residence.
} 
Bearing in mind the intentions of the Community legislator, it can be concluded that the application of the concept of habitual residence ensures in the best way free movement of persons within the EU, which is one of the main objectives of Community law, as well as the fusion of diverse population living in the EU territory, so the choice of community legislator seems quite logical. Having in mind that concept of habitual residence and the principle of nationality are mutually exclusive, the following reasons may be cited in supporting the view that the interests of the child habitually resident in the EU are best protected by this concept ${ }^{8}$ :

- There is a strong connection between the country aiming to exercise jurisdiction to protect the child and the child and his family members, since that country constitutes current social environment of the child. On the other side, the child may have never had, or may have lost any real connection to the country of nationality; additional problems may arise if the child has more than one nationality;

- Almost all international documents ${ }^{9}$ pertaining to this matter gave priority to the concept of habitual residence over the principle of nationality;

- The authorities of child's habitual residence are better placed to make decisions in terms of child's interests from procedural and economical point of view, since inquiries, investigations and hearings ${ }^{10}$ can be carried out more easily,

- Habitual residence ensures the free movement of persons which is one of the main principles of Community Law.

\footnotetext{
${ }^{8}$ Duncan, W., op. cit., p. 80. Richez-Pons, A., Habitual Residence Considered as a European Harmonization Factor in Family Law (Regarding the Brussels II bis Regulation), in Boele-Woelki, K. (ed.), European Family Law in Action, Parental Responsibilities, Intersentia, Volume III, 2005., p. 356360.

${ }^{9}$ See for example Hague Convention of 1996 and Hague Convention of 25 October 1980 on the Civil Aspects of International Child Abduction.

${ }^{10}$ Especially relevant here is the right of the child to be heard in judicial or administrative proceedings affecting the child. See Article 12, paragraph 2 of the Convention on the Rights of the Child, adopted by the General Assembly of the UN on 20. 1. 1989.
}

According to the Article 8 paragraph 1 of the Brussels II bis Regulation, general jurisdiction of the courts of the Member States in cases of parental responsibility is determined by the child's habitual residence at the time the court is seized. Habitual residence is the basic concept when it comes to applying the exceptions to the general rule provided by Article 9, 10 and 12 of the Brussels II bis Regulation in the following cases:

Continuing jurisdiction of the child's former habitual residence (Article 9 of the Brussels II bis Regulation).

Specifically, the application of Article 9 of the Regulation as an exception from the application of general jurisdiction specified in Article 8 Paragraph 1 is possible after the courts of the Member State of the child's former habitual residence issued a judgment on access rights and the child was lawfully taken to another Member State, where he acquired a new habitual residence. In this case, the courts of the Member State of child's former habitual residence retain jurisdiction over the three-month period, in order to change a court decision on the right of accession issued in that Member State before the child's movement, if the holder of access rights still has his habitual residence in the Member State of the child's former habitual residence. However, this rule does not apply if the holder of access rights has accepted jurisdiction of the courts of a Member State in which the child has a new habitual residence, in a way that he participated in proceedings before those courts, not contesting their jurisdiction.

- Jurisdiction in cases of child abduction ${ }^{11}$ (Article 10 of the Brussels II bis Regulation).

In the case of wrongful removal or retention of the child, the courts of the Member State where the child was habitually resident immediately before the wrongful removal or retention retain their jurisdiction until the child has acquired habitual residence in another Member State, as well as any person, institution or other body with the right to custody has acquiesced in the removal or retention, or until the child has resided in a Member State for a period of

\footnotetext{
${ }^{11}$ For definition of"wrongful removal or retention", see Article 2 paragraph 11 of the Brussels II bis Regulation. See also article 3 to 5 of Hague Convention of 25 October 1980 on the Civil Aspects of International Child Abduction.
} 
at least one year after the person, institution or other body with the rights to custody has had or should have had knowledge of the whereabouts of the child and the child is settled in his/her new environment, and at least one of the conditions is met: i) within one year from the date the holder of rights to custody has had or should have acquired knowledge about where the child is, there has not been submitted a request for return of the child before the competent authorities of the Member State in which the child has been moved or is being retained, or ii) that the request for the return of a child submitted by the holder of rights of custody withdrawn, and no new request has been lodged within the period specified in (i) or iii) that the case before the court of the Member State where the child was habitually resident immediately before the unlawful removal or retention has been closed in accordance with the provisions of Article 11 paragraph 7, or iv) that the court of a Member State in which the child was habitually resident immediately before the unlawful removal or retention has issued a judgment on custody that does not entail the return of the child.

The provision of Article 10 of the Brussels II bis Regulation needs to be considered in correlation with the provision of Article 8 paragraph 1, and the provisions of this Act relating to the recognition and enforcement of foreign court decisions in this matter (Chapter III). The provision of Article 10 of the Regulation provides for the continuing jurisdiction of the courts of a Member State in which the child immediately before the unlawful removal or retention was habitually resident, while in the same time determines preconditions for the establishment of the international jurisdiction of the court of a Member State to which the child has been taken, or where the child is retained along with the fulfillment of one of the aforementioned conditions. In this way, by the fulfillment of any of these conditions, the child acquires habitual residence in that new Member State, so the question of jurisdiction in this case has to be observed in the context of Article 8 Paragraph 1 of the Brussels II bis Regulation. In addition, Article 10 of the Regulation gives a possibility to the holder of the custody rights within one year to submit a request for the return of the child before the courts of the Member State where the child was habitually resident immediately before the wrongful removal or retention, and thereafter seek enforcement of the decision entailing the return of the child before the courts of the Member States to which the child is unlawfully taken or retained in accordance with the provisions of Chapter III of this Regulation ${ }^{12}$. In this way, the holder of the rights of custody can avoid the application process for the return of the child before the courts of the Member State in which the child is unlawfully taken, which must be implemented in accordance with the provisions of the Hague Convention on the Civil Aspects of International Child Abduction and Article 11 of the Brussels II bis Regulation.

- Prorogation of jurisdiction (Article 12 of the Brussels II bis Regulation);

In matters of parental responsibility Brussels II bis Regulation gives a limited possibility for prorogation of jurisdiction in favor of the courts of the Member State in which there is no child's habitual residence. It will be possible in two cases:

a) the attraction of jurisdiction in matters of parental responsibility in proceedings in matrimonial matters and,

b) if there is a significant relationship between the child and Member State whose court jurisdiction is prorogated, and the procedure is not related to the matrimonial dispute.

In the first case, the attraction of jurisdiction is possible with cumulative fulfillment of the following assumptions: that at least one of the spouses has full parental responsibility in relation to the child ${ }^{13}$, that spouses, and holders of parental responsibility (one of which must not be spouse) explicitly or in some other unambiguous manner accept the jurisdiction of the courts at the time the court is seized, and if it is in the best interest of the child.

\footnotetext{
${ }^{12}$ See more Stone, P., EU Private International Law: Harmonization of Laws (Elgar European Law), Edward Elgar Publishing Ltd., 2006, p. 422.

${ }^{13}$ Article 2, paragraph 7 of the Brussels II bis Regulation.
} 
As the moment of prorogation agreement is connected to the time the court is seized, which is determined according to article 16 of the Regulation, the question is whether the momentum of court seizing is associated with the proceedings in matrimonial matters or matters of parental responsibility? ${ }^{14}$ However, given the fact that consent (tacit or explicit) must be given not only by the persons whose marital dispute is pending before the court of the Member State, but also by the holders of parental responsibility, one of which must not be a spouse, we consider the time the court is seized has to be connected to parental responsibility matter.

Attraction of jurisdiction in matters of parental responsibility takes so long until one of alternatively set conditions specified in paragraph 2 Article 12 of the Regulation is fulfilled.

Another case which provides for the possibility of prorogation of jurisdiction in matters of parental responsibility refers to the existence of a significant relationship of the child with the Member State, although the procedure is not connected to matrimonial matters. The relationship that exists between the child and the Member States must be substantial ${ }^{15}$, given that it excludes the application of general rule of international jurisdiction, and accordingly the establishment of jurisdiction of the courts of another Member State. According to the provision of Article 12 Paragraph 3 of the Regulation, the child has a substantial connection with the Member State, especially if one of the holders of parental responsibility has his/her habitual residence in that State or the child is a national of that Member State. The term "especially" indicates that the assumptions made in the aforementioned paragraph of Article 12 do not have exclusive character, and that the finding of a substantial connection of the child with the Member State can be made and based on the existence of other binding conditions, such as those referred to in Article 15 paragraph 3 of this Regulation.

\footnotetext{
${ }^{14}$ Rauscher, T., Parental Responsibility Cases under the New Council Regulation "Brussels II A", The European Legal Forum (E), 2005, No. 1, p. 40.

${ }^{15}$ Practice Guide for the Application of the New Brussels II Regulation, Up-dated version 1 June 2005, p. 17, http:// ec.europa.eu/civiljustice/divorce/parental_resp_ec_vdm en.pdf, visited 01. 03. 2011.
}

In addition to the above assumptions, just as in the case of attraction of jurisdiction, additional conditions are required to be met: that at the time the court is seized, jurisdiction of the courts has been accepted by all parties, and that the jurisdiction of the court of that Member State is in the best interests of the child. It is evident from article 12 paragraph 4 of the Regulation that the provision on prorogation of jurisdiction in matters of parental responsibility can be applied regardless of whether the child is habitually resident in another Member State or third country, where one must take into account that the prorogated jurisdiction of the court of the Member States is in the best interests of the child. This will be the case when the child is habitually resident in a third country other than the Parties of the Hague Convention on Jurisdiction, Applicable Law, Recognition, Enforcement and Cooperation in Respect of Parental Responsibility and Measures for the Protect of Children from 1996, especially if it is determined that it is not possible to conduct the proceedings in a third country in question $^{16}$.

If the child's habitual residence can not be determined in the ways described above, the courts of the Member State where the child is present shall have jurisdiction (Article 13 of the Brussels II bis Regulation). The rule on the jurisdiction of the courts of the Member State where the child is present applies also in the case when it comes to children who are refugees or internationally displaced because of disturbances in their country. If neither of the last method can determine the jurisdiction, an option is the application of the principle of lex fori (Article 14 of the Brussels II bis Regulation). In accordance with the principle of proximity or special relationship of the child with particular state, as well as the child's best interest, the courts of a Member State having jurisdiction as to the substance of the matter may, exceptionally, at the request of a party or ex officio, transfer the case to a court better placed to hear it (Article 15, paragraph 1 and 2 of the Regulation).

${ }^{16}$ Borrás, A., Council Regulation (EC) No 1347/2000 of 29 May 2000 on Jurisdiction and the Recognition and Enforcement of Judgments in Matrimonial Matters and in Matters of Parental Responsibility for Children of Both Spouses („Brussels II Regulation“) and Regulation (EC) No 2201/2003 Repealing It („Brussels II a Regulation“), Civil Law, European Judicial Cooperation, European Communities, 2005, p. 61. 
It is considered that the child is especially connected to a particular Member State if in that Member State:

- Child acquired habitual residence after the court of that state having jurisdiction as to the substance of the matter was seized;

- was former habitual residence of the child;

- If the child is a national of that Member State,

- If the holder of the rights to custody of the child is habitually resident in that state, and

- If that state is the place where property of the child is located, and the case concerns measures for the protection of the child relating to the administration, conservation or disposal of this property (Article 15, paragraph 1,2 and 3 of the Regulation).

Temporal component of the concept of habitual residence is evaluated depending on the moment the court is seized (Article 8 paragraph 1 of the Regulation) ${ }^{17}$.

\section{EUROPEAN COURT OF JUSTICE INTERPRE- TATION OF THE CONCEPT OF "HABITUAL RESIDENCE": MERCREDI V. CHAFFE}

Brussels II bis Regulation does not give a definition of "habitual residence" of the child for the purposes of application of this Act in matters of parental responsibility. However, it is clear from the declared objectives of the Regulation that the concept must be defined in a spirit of community law ${ }^{18}$. In other words, child's best interests can not be ensured if in determination of the concept of "habitual residence" of the child is taken a different approach in the EU Member States in accordance with their domestic law. Even case law of the European Court of Justice relating to the interpretation of this concept in other areas of law cannot be relevant in terms of the assessment of the habitual residence of children for the purpose of article 8 paragraph 1 of the Regulation ${ }^{19}$.

\footnotetext{
${ }^{17}$ Article 16 paragraph 1 (a) (b) of Brussels II bis Regulation.

${ }^{18}$ Paragraph 12 of the Preamble to the Regulation.

${ }^{19}$ Case 523/07 (2009) ECR I-2805, paragraph 36. Magnus/ Mankowski/Borras, A., Brussels II bis Regulation, European Law Publishers, 2012, p. $113-115$.
}

According to the Court in C- 523/07 "the habitual residence of a child, within the meaning of article $8(1)$ of the Regulation must be established on the basis of all the circumstances specific to each individual case" ${ }^{20}$. It is therefore necessary to give this concept an independent meaning, taking into account the purposes of the Regulation and the general principles underlying the legislation of the Member States. However, individuality of each case prevents defining this concept in general and abstract terms ${ }^{21}$. In a decision from 2010 brought by the European Court of Justice in case the Barbara Mercredi v.Richard Chaffe ${ }^{22}$, the Court established the parameters that competent courts should take into consideration in order to ensure uniform interpretation of the concept of "habitual residence" of the child. It is necessary to bear in mind the need for uniform interpretation and application of Community law in general and the objectives set by the Regulation, which primarily relates to the principle of proximity and the protection of the interests of the child ${ }^{23}$.

${ }^{20} \mathrm{Ibid}$, paragraph 37.

${ }^{21}$ Richez-Pons, A., op. cit., p. 356 - 357. Verschraegen, B., Critical appraisal of the Brussels IIa Regulation, International Conference „Regional cooperation in the field of civil proceedings with international element", Collection of papers,

Banja Luka, 2009, p. 24.

${ }^{22}$ Barbara Mercredi v. Richard Chaffe, C-497/10 PPU, from 22.12. 2010. According to documents submitted to the Court, it was determined that Ms Mercredi, born on the Reunion was a French national who, after her employment in an airline company, moved to England. She has lived in a registered partnership with Mr Chaffe for a couple of years, when this couple in 2009 got a daughter, named Cloe, who acquired French citizenship. Seven days after the child's birth, the couple split up. On October, 7, 2009, Ms Mercredi left England with twomonth old baby and returned to Reunion, where they arrived next day. The father of the child was not informed of this departure, but on October, 10, 2009 he got a letter in which Ms Mercredi explained the resons why she left England. It was the fact that habitual residence of the child before her departure to Reunion was in England. It was also the fact that removal of the child to Reunion was not wrongful, since in that moment Ms Mercredi was the only one who had a right of custody according to article 2 paragraph 9 of Brussels II bis Regulation. In connection with this case English court addressed the European Court of Justice in terms of defining the concept of "habitual residence" of the child in the context of application of Article 8 and 10 of the Brussels II bis Regulation.

${ }^{23} \mathrm{Ibid}$, paragraph 45 and 46. 
Therefore, the European Court of Justice, taking into account all the circumstances of the case (child's age, family environment, family and geographic origin of the parents with right of custody, the intention of the person who is entitled to the custody to settle in certain Member State, etc.), argued that the concept of "habitual residence" means a degree of integration by the child in social and family environment. Defining the concept of "habitual residence" in matters of parental responsibility depends to a large extent on the age of the child and his needs ${ }^{24}$. Therefore, when an infant has spent a certain period of time with her mother in a Member State other than the Member State of her habitual residence, the factors needed to be taken into account for determination of habitual residence include primarily the duration, regularity, conditions and reasons for the arrival and stay in the territory of a Member State, and having in mind the child's age, geographic and family origin of mother as well as family and social ties that mother and child have in that Member State. Taking into account all relevant facts (factual and voluntary elements) ${ }^{25}$ that are specific for each individual case, it is up to court to determine the child's habitual residence ${ }^{26}$.

\section{INTERNATIONAL JURISDICTION RULES IN MATTERS OF PARENTAL RESPONSIBIL- ITY IN THE LEGISLATION IN BOSNIA AND HERZEGOVINA}

Constitution of Bosnia and Herzegovina ${ }^{27}$ has made the division of competencies between the state and entity levels. The initial concept of this constitutional act is the enumeration of the competencies of the institutions of Bosnia and Herzegovina (article III/1.) with presumption of competencies in favor of entities (article III/3.a).

\footnotetext{
${ }^{24}$ Ibid, paragraph 53.

${ }^{25}$ Stone, P., op. cit., p. $411-413$.

${ }^{26}$ Mercredi v. Chaffe, paragraph 56.

${ }^{27}$ Dayton Peace Agreement signed in Paris on December, 14, 1995. More on the constitutional structure of B\&H and division of competencies see Trnka, K., Ustavno pravo, Pravni fakultet Univerziteta u Bihaću, Sarajevo, 2000, p. 324 - 325.
}

According to it, the area of private law relations, including private international law issues is under the jurisdiction of entities - Republic of Srpska and the Federation of Bosnia and Herzegovina. After dissolution of Yugoslavia, the Act on the Collision of Laws with Laws of Foreign Nations in Certain Cases (hereafter: PIL Act) ${ }^{28}$ was taken over into the legislation of both of entities in Bosnia and Herzegovina and is currently applicable unchanged.

Contrary to the rules of Brussels II bis Regulation concerning rules on jurisdiction in matters of parental responsibility which gave primacy to the concept of habitual residence, PIL Act accepts as the main principle of nationality. However, it is not unusual having in mind that former Yugoslavia and consequently B\&H and other countries in the region are the countries with a huge emigration of population. Therefore, the intention of the legislator was to keep the connections between citizens of B\&H with their native country by using the principle of nationality not only in terms of rules on jurisdiction but also choice of law rules ${ }^{29}$.

Thus, with respect to the aforementioned subject of Brussels II bis Regulation ${ }^{30}$, jurisdiction of $\mathrm{B} \& \mathrm{H}$ authorities exists in disputes relating to the care of the person of the child, raising and fostering of children who are under custody, even when the defendant has no domicile in $\mathrm{B} \& \mathrm{H}$, if both parents are nationals of Bosnia and Herzegovina (Article 66, paragraph 1 of the PIL Act). The child's nationality is irrelevant, as well as his domicile ${ }^{31}$. If, however, the defendant and the child are $\mathrm{B} \& \mathrm{H}$ nationals and both have domicile in $\mathrm{B} \& \mathrm{H}$, the $\mathrm{B} \& \mathrm{H}$ Court's jurisdiction is exclusive.

In terms of specific segments of parental responsibility (deprivation and restoration, and renewal of parental responsibilities), bearing in mind the fact that some legal issues in this area are excluded from the scope of Regulation $^{32}$, the jurisdiction of the courts in $\mathrm{B} \& \mathrm{H}$

\footnotetext{
${ }^{28}$ Official Gazette of SFRY, No. 43/1982, 72/82, Official Gazette of B\&H, No. 2/92, 13/94.

${ }^{29}$ Varadi, T., Bordaš, B., Knežević, G., Međunarodno privatno pravo, Forum, Novi Sad, 2005, p. 255 - 256.

${ }^{30}$ It is important to emphasize that parental responsibility under the Brussels II bis Regulation is not completely compatible with this subject matter regulated by PIL Act in B\&H.

${ }^{31}$ Dika, M (et. Al.), Komentar Zakona o međunarodnom privatnom i procesnom pravu, Nomos, Beograd, 1991, p. 223.

${ }^{32}$ Article 1, paragraph 3 of the Brussels II bis Regulation.
} 
exists, even when requirements from Article 46 paragraph 4 of the PIL Act are not met, if the applicant and the defendant are nationals of $\mathrm{B} \& \mathrm{H}$, or when the procedure involved only one person if that person is a national of Bosnia and Herzegovina (Article 69 of the PIL Act).

In relation to nationals of $\mathrm{B} \& \mathrm{H}$, the authorities in $\mathrm{B} \& \mathrm{H}$ will have exclusive jurisdiction in matters of custody, regardless of where these persons have their domicile, unless PIL Act provides otherwise (article 75. of the PIL Act). The authority in B\&H will not bring a decision or take a measure in matters of custody of B\&H nationals with their domicile abroad, if it finds out that the authority competent under the law of that State has brought a decision or taken measures to ensure protection of personality, rights and interests of B\&H nationals (article 76 of the PIL Act). Also, the authority in B\&H will take the necessary provisional measures to protect the personality, rights and interests of a foreign national who is or has assets in $\mathrm{B} \& \mathrm{H}$, about what it will inform the authority of the state whose national that person is. B\&H authority shall bring a decision and take measures in matters of custody of a foreign national who has domicile in $\mathrm{B} \& \mathrm{H}$, if the protection of his personality, rights and interests has not been provided by the authority of the state whose national he is (article 77 of the PIL Act).

\section{POSSIBILITY FOR B\&H TO ENTER INTO CONTRACTUAL RELATIONS WITH THE EU MEMBER STATES IN MATTERS OF PAREN- TAL RESPONSIBILITY}

External competence of the EU to enter into contractual relations with third countries and international organizations in the field of private international law is determined by the existence of inter-european competence to address the issues in this field, as well as through the realization of such competence by Community legal instruments ${ }^{33}$. Analogously, the member states have lost the possibility to conclude international agreements with third countries, including Bosnia and Herzegovina, in areas of private international law, which are, on the Community level, determined by community legal instruments regulations.
Analogously, the member states have lost the possibility to conclude international agreements with third countries ${ }^{34}$, including Bosnia and Herzegovina, in areas of private international law, which are, on the Community level, determined by community legal instruments - regulations. Exceptionally, according to the rules of the Regulation (EC) No. 664/2009 35 and under certain conditions,

${ }^{33}$ See: Kotuby, C., Internal Developments and External Effects: the Federalization of Private international Law in the European Community and its Consequences for Transnational Litigants, Journal of Law and Commerce, 21/2002, p. 158 180. Basedow, J., The Communitarization of the Conflict of Laws under the Treaty of Amsterdam, Common Market Law Review, Vol. 37, 2000, p. 701 - 705. Brand, R. A., The European Union's New Role in International Private Litigation, Chicago International Law Review, Loyola University, Vol. 2, issue 2, 2004 - 2005, p. 285 - 291. Cremona, M., A Constitutional Basis for Effective External Action? An Assessment of the Provision on EU External Action in the Constitutional Treaty, European University Institute, No. 2006/30, http://cadmus.iue.it/dspace/index.jsp, last visited 30. 12. 2011. Dickinson, A., European Private international Law: Embracing New Horizons or Mourning the Past?, Journal of Private International Law, 2005, p. 207 - 217. Holdgaard, R., The European Community's Implied External Competence after the Open Skies Cases, European Foreign Affairs Review, Vol. 8, 2003, p. 365 - 394. Staudinger, A., Leible, S., Article 65 of the EC Treaty in the EC System of Competencies, The European Legal Forum (E), 4-2000/01, p. 225 - 235.

${ }^{34}$ See: Geiger, R., External Competences of the European Union and the Treaty-making Power of its Member States, Arizona Journal of International and Comparative Law, Vol. 14, No. 2, 1997, p. 323 - 325. Hartnell, H.E., Eustitia: Institutionalizing Justice in the European Union, Northwestern Journal of International Law and Business, Vol. 23, 2002, p. 65 - 137. Borrás, A., Competence of the Community to Conclude the Revised Lugano Convention on Jurisdiction and the Recognition and Enforcement of Judgments in Civil and Commercial Matters - Opinion C-1/03 of 7 February 2006: Comments and Immediate Consequences, Yearbook of Private International Law, Vol. VIII, 2006, p. 37 - 53.

${ }^{35}$ Council Regulation (EC) No. 664/2009 of 7 July 2009 establishing a procedure for the negotiation and conclusion of agreements between Member states and third countries concerning jurisdiction, recognition and enforcement of judgments and decisions in matrimonial matters, matters of parental responsibility and matters relating to maintenance obligations, and the law applicable to matters relating to maintenance obligations, Official Journal of the European Union, L 200/46, 31. 7. 2009. 
there is a possibility for the member states to enter into contractual relations with third states ${ }^{36}$ even in areas that are on the inner (community) level regulated by the Brussels II bis Regulation and Regulation (EC) No. 4/2009 ${ }^{37}$. In other words, there is a possibility for B\&H to conclude agreement(s) with Member state(s), among other issues, in terms of jurisdiction in matters of parental responsibility. This option is of immense importance for Bosnia and Herzegovina, for the war and post-war events that befell this region were the catalyst for a migration of the large percentage of the population from B\&H to EU Member States. With some of these states (Germany, Denmark, the Netherlands, United Kingdom) B\&H has never concluded international agreements ${ }^{38}$, although there is a real need for them, bearing in mind the number of $\mathrm{B} \& \mathrm{H}$ nationals who live in these countries.

In addition, according to the Stabilization and Association Agreement, B\&H undertook the obligation to harmonize its legislation with the relevant part of acquis communautaire, so the acceptance of the concept of habitual residence in relation to the rules on international jurisdiction in matters of parental responsibility as well as its implementation in B\&H legislation seems quite justified.

\footnotetext{
${ }^{36}$ Alihodžić, J., Uticaj vanjske nadležnosti Evropske unije na sklapanje međunarodnih ugovora država članica u oblasti Međunarodnog privatnog prava - osvrt na Uredbu EZ br. 664/2009 i njen značaj za BiH, Anali Pravnog fakulteta Univerziteta u Zenici, br. 6, godina 3, 2010, p. 73 - 91.

${ }^{37}$ Council Regulation (EC) No 4/2009 of 18 December 2008 on Jurisdiction, Applicable law, Recognition and Enforcement of Decisions and Cooperation in Matters relating to Maintenance Obligations, Official Journal of the European Union, L 7/1, 10. 01. 2009.

${ }^{38} \mathrm{By}$ notification of succession, $\mathrm{B} \& \mathrm{H}$ has taken over certain number of bilateral agreements concluded between the former Yugoslavia and some EU Member States, which wholly or partially fall under the Regulation (EC) No. 664/2009. These agreements are still in force in $\mathrm{B} \& \mathrm{H}$ due to the article 24, paragraph 1 of the Vienna Convention on Succession of States in Respect of Treaties 1978, done at Vienna on 23 August 1978, entered into force on 6 November 1996, United Nations, Treaty Series, Vol. 1946, p. 3. See more in Alihodžić, J., op. cit., p. 88 - 90.
}

\section{CONCLUDING REMARKS}

The primary criterion for determining the jurisdiction of the courts in accordance with the solutions of the Brussels II bis Regulation is child's habitual residence at the time the court is seized. As the Regulation does not contain an autonomous definition of this concept, the European Court of Justice interpretation given in the decision Mercredi v. Chaffe is of immense importance.

On the other hand, the aforementioned provisions of the PIL Act show that B\&H legislator, in addition to the general criteria for determining rules of jurisdiction based on defendant's domicile, opted for the principle of nationality in terms of determining the rules of jurisdiction of $\mathrm{B} \& \mathrm{H}$ authorities in matters of parental responsibility, which substantially differ from the solution of community legislator, who accepts the principle of habitual residence. In both cases (communitarian and B\&H legislation), the motivation for the selection of specified criteria is based on the need to protect the interests of the child.

We should not forget the possibility of concluding bilateral agreements in this field with the Member States in accordance with Regulation 664/2009, where the concept of habitual residence would probably have primary importance.

When it comes to the reform of the legislation in $\mathrm{B} \& \mathrm{H}$, if the child's interests are sufficiently protected by the existence of the jurisdiction rules based on the principle of nationality, B\&H legislator should not leave the existing solutions, but rather supplement the already existing provisions by introducing the concept of habitual residence as a subsidiary criterion for determining jurisdiction of authorities in this matter. Should the legislature chose to adopt such a provision, it would mean that courts in $\mathrm{B} \& \mathrm{H}$ proceeding in these cases need to take into account the interpretation of the concept of habitual residence given by the European Court of Justice in order to achieve greater uniformity in the application of this principle among Member States and those countries that intend to become one. 


\section{REFERENCES}

Alihodžić, J. (2010). Uticaj vanjske nadležnosti Evropske unije na sklapanje međunarodnih ugovora država članica u oblasti Međunarodnog privatnog prava - osvrt na Uredbu EZ br. 664/2009 i njen značaj za BiH, Anali Pravnog fakulteta Univerziteta u Zenici, br. 6, godina 3.

Basedow, J. (2000). The Communitarization of the Conflict of Laws under the Treaty of Amsterdam, Common Market Law Review, Vol. 37.

Blagojević, B. (et. al.), Nacrt zakona o međunarodnom privatnom pravu i postupku, Prinosi, br. 7/74.

Borrás, A. (2006). Competence of the Community to Conclude the Revised Lugano Convention on Jurisdiction and the Recognition and Enforcement of Judgments in Civil and Commercial Matters - Opinion C-1/03 of 7 February 2006: Comments and Immediate Consequences, Yearbook of Private International Law, Vol. VIII.

Borrás, A. (2005). Council Regulation (EC) No 1347/2000 of 29 May 2000 on Jurisdiction and the Recognition and Enforcement of Judgments in Matrimonial Matters and in Matters of Parental Responsibility for Children of Both Spouses („Brussels II Regulation“) and Regulation (EC) No 2201/2003 Repealing It („Brussels II a Regulation“), Civil Law, European Judicial Cooperation, European Communities.

Brand, R. A. (2004 - 2005). The European Union's New Role in International Private Litigation, Chicago International Law Review, Loyola University, Vol. 2, issue 2, (2004 - 2005).

Cremona, M. A Constitutional Basis for Effective External Action? An Assessment of the Provision on EU External Action in the Constitutional Treaty, European University Institute, No. 2006/30, http://cadmus.iue.it/dspace/index.jsp, last visited 30. 12. 2011.

Dickinson, A. (2005). European Private international Law: Embracing New Horizons or Mourning the Past?, Journal of Private International Law.

Dika, M (et. Al.) (1991). Komentar Zakona o međunarodnom privatnom i procesnom pravu, Beograd, Nomos.

Duncan, W. (2006). Nationality and the Protection of Children across Frontiers, and the Example of Inter-country Adoption, Yearbook of Private International Law, Volume 8.

Geiger, R. (1997). External Competences of the European Union and the Treaty-making Power of its Member States, Arizona Journal of International and Comparative Law, Vol. 14, No. 2.

Hartnell, H.E. (2002). Eustitia: Institutionalizing Justice in the European Union, Northwestern Journal of International Law and Business, Vol. 23.

Holdgaard, R. (2003). The European Community's Implied External Competence after the Open Skies Cases, European Foreign Affairs Review, Vol. 8.
Kotuby, C. (2002). Internal Developments and External Effects: the Federalization of Private international Law in the European Community and its Consequences for Transnational Litigants, Journal of Law and Commerce, 21.

Magnus/Mankowski/Borras, A. (2012). Brussels II bis Regulation, European Law Publishers.

Rauscher, T. (2005). Parental Responsibility Cases under the New Council Regulation "Brussels II A", The European Legal Forum (E), No. 1.

Richez-Pons, A. (2006). Habitual Residence Considered as a European Harmonization Factor in Family Law (Regarding the Brussels II bis Regulation), in Boele-Woelki, K. (ed.), European Family Law in Action, Parental Responsibilities, Intersentia, Volume III.

Rosenblatt, J. (2000). International Conventions Affecting Children, Kluwer Law International.

Stanivuković, M., Živković, M. (2010). Međunarodno privatno pravo, opšti deo, Službeni glasnik.

Staudinger, A., Leible, S. Article 65 of the EC Treaty in the EC System of Competencies, The European Legal Forum (E), 4-2000/01;

Stone, P. (2006). EU Private International Law: Harmonization of Laws (Elgar European Law), Edward Elgar Publishing Ltd.

Šaula, V. (2008). Osnovi međunarodnog privatnog prava Republike Srpske, Pravni fakultet Univerziteta u Banjoj Luci.

Trnka, K. (2000). Ustavno pravo, Pravni fakultet Univerziteta u Bihaću, B\&H, Sarajevo.

Varadi, T., Bordaš, B. and Knežević, G. (2005). Međunarodno privatno pravo. Serbia, Novi Sad. Forum.

Verschraegen, B. (2009). Critical appraisal of the Brussels IIa Regulation, International Conference „Regional cooperation in the field of civil proceedings with international element", Collection of papers, B\&H, Banja Luka.

Act on the Collision of Laws with Laws of Foreign Nations in Certain Cases (Official Gazette of SFRY, No. 43/1982, $72 / 82$ );

Convention on the Rights of the Child, adopted by the General Assembly of the UN on 20. 1. 1989;

Council Regulation (EC) No 2201/2003 of 27 November 2003 concerning Jurisdiction and the Recognition and Enforcement of Judgments in Matrimonial Matters and the Matters of Parental Responsibility, repealing Regulation (EC) No 1347/2000, Official Journal of the European Union L338/1, 23. 12. 2003;

Council Regulation (EC) No 4/2009 of 18 December 2008 on Jurisdiction, Applicable law, Recognition and Enforcement of Decisions and Cooperation in Matters relating to Maintenance Obligations, Official Journal of the European Union, L 7/1, 10. 01. 2009. 
Council Regulation (EC) No. 664/2009 of 7 July 2009 establishing a procedure for the negotiation and conclusion of agreements between Member states and third countries concerning jurisdiction, recognition and enforcement of judgments and decisions in matrimonial matters, matters of parental responsibility and matters relating to maintenance obligations, and the law applicable to matters relating to maintenance obligations, Official Journal of the European Union, L 200/46, 31. 7. 2009. Hague Convention of 1996 and Hague Convention of 25 October 1980 on the Civil Aspects of International Child Abduction.
Hague Convention on Jurisdiction, Applicable Law, Recognition, Enforcement and Cooperation in Respect of Parental Responsibility and Measures for the Protection of Children, 19 October 1996;

Practice Guide for the Application of the New Brussels II Regulation, Up-dated version 1 June 2005, p. 17, http:// ec.europa.eu/civiljustice/divorce/parental_resp_ec_vdm en.pdf, visited 01. 03. 2011,

Vienna Convention on Succession of States in Respect of Treaties 1978, done at Vienna on 23 August 1978, entered into force on 6 November 1996, United Nations, Treaty. 